\title{
Ovarian Ectopic Pregnancy: A Rare Case
}

\author{
Authors \\ Dr Soumya ${ }^{1}$, Dr Soma Bandhyopadhyay ${ }^{2}$, Dr Sipra Singh ${ }^{3}$, \\ Dr Shilpi Chowdhury ${ }^{4}$, Dr Bhagyashree ${ }^{5}$ \\ ${ }^{1}$ PGT $2{ }^{\text {nd }}$ year, Dept. of Obstetrics \& Gynaecology, KMCH \\ ${ }^{2}$ Professor, Dept. of Obstetrics \& Gynaecology, KMCH \\ ${ }^{3}$ Professor, Dept. of Obstetrics \& Gynaecology, KMCH \\ ${ }^{4}$ PGT $3{ }^{\text {rd }}$ year, Dept. of Obstetrics \& Gynaecology, KMCH \\ ${ }^{5}$ PGT $3{ }^{\text {rd }}$ year, Dept. of Obstetrics \& Gynaecology, KMCH
}

\section{Introduction}

Ovarian ectopic pregnancy is a rare varient of ectopic implantation. It ends with rupture before the end of $1^{\text {st }}$ trimester because of increase vascularization of the ovarian tissue which leads to internal hemorrage and hypovolemic shock.

Its incidence after natural conception ranges from 1 in 2000 to 1 in 6000 deliveries, and accounts for $3 \%$ of all ectopic pregnancy one in every ectopic pregnancies among intrauterine device users is an ovarian pregnancy.

The diagnosis is intricated and based on surgical and histological observation. Ectopic pregnancy implanted in the ovary is rare. Traditional risk factor for ovarian ectopic pregnancy are similar to those of tubal pregnancy but use of IUD is disproportionately associated.

\section{Aim}

To present a case of successful laprotomy for ovarian ectopic pregnancy

Setting: Department of obstetrics and Gynaecology Katihar Medical College, Katihar

\section{Case Summary}

A, 33 years old multigravida with 1 and half months of amenorrhea presented in obstetrics casualty with chief complain of pain abdomen since 3 days. Pain was all over the abdomen with no aggravating or relieving factor. Pain was continuous and radiated to left shoulder. There was also history of nausea and syncopal attack there was also history of spotting $\mathrm{P} / \mathrm{V}$ since 3 days. Her previous menstrual cycle was normal. There was no significant past, personal or surgical history.

\section{On Examination}

$$
\begin{aligned}
& \mathrm{BP}-90 / 70 \mathrm{mmHg} \\
& \mathrm{P} / \mathrm{R}-96 \mathrm{bpm} \\
& \text { Febrile, Temp }-100^{\circ} \mathrm{F} \\
& \text { Pallor ++ }
\end{aligned}
$$

No icteurs, cynosis, clubbing, lymphadenopathy. Per abdomen:-

\section{Tenderness ++}

Distension + Immediately preliminary investigations and USG was done 


\section{Investigation}

$\mathrm{Hb}-8.5$

Plt -1.2

ABORh - AB Positive

RBS - 120

Sr. Urea -26

Sr. Creatinine -0.7

Sr. Bilirubin -0.8

SGOT - 21

SGPT - 19

TLC -12500

USG - A hetrogenous mass lesion with dense fluid collection around the lesion in the right adenexa

S/o ruptured ectopic pregnancy

S/o hemoperitonium with mild bulky uterus.

\section{Operative Procedure}

After all preliminary investigations patient was taken for emergency laprotomy in view of suspected right ovarian ectopic pregnancy $\downarrow$ G/A with $\mathrm{A} / \mathrm{S} / \mathrm{P}$ patient was laid in supine position. Abdomen was painted \& drapped. A low transverse incision was given $2.5 \mathrm{~cm}$ above pubic symphysis. Abdomen was opened in layers. Peritonium was opened. Blood was Suctioned out and ruptured right ovarian pregnancy was identified and explored. Right sided salphingoophrectomy was done \& left sided fimbrectomy was done. Peritonial cavity was washed with normal saline. Hemostasis was achieved and abdomen was closed in layers. Specimen was sent for histopathological examination.

Post Operative Period: She was given injectable antibiotics. Post operative period was uneventful and patient was discharged on $8^{\text {th }}$ post operative day and to be followed on OPD basis. Histopathology report showed chorionic villi

\section{Discussion}

Pathophysiology: Ovarian ectopic pregnancy occurs when a fertilized ovum implants on the surface of the ovary. It can be categorized into primary \& secondary classification. Primary ovarian ectopic usually occurs due to ovulatory dysfunction and the ovum is fertilized while still within the follicles, before the follicles being expelled from the ovary.

Secondary ovarian ectopic pregnancy occurs when the fertilization takes place within the fallopian tube and the conceptus is regurgitated and implanted in the ovarian stroma.

Sign \& Symptoms of ovarian ectopic pregnancy:

$>$ Mild to moderate lower abdominal pain

$>$ Vaginal bleeding

$>$ Nausea

$>$ Vomiting

$>$ Constipation

$>$ Hypovolumic shock (if ruptured)

Examination Finding: Clinical examination and lab finding include lower abdominal tenderness with or without rigidity or gaurding, vaginal bleeding, adenexal tenderness, positive pregnancy test and elevated $\beta$ - hcg level.

Diagnostics Evaluation: In hemodynamically stable patient further diagnostic evaluation should include TVS. Correlation of serial quantitative $\beta$ HCG level measurements with TVS finding can aid in accurate interpretation. Usually an intrauterine gestational sac can be visualized on transvaginal USG when quantitative $\beta-\mathrm{HCG}$ level > $2000-3000$ IU/L

Sonographic finding for presence of ovarian ectopic pregnancy

$>$ An empty endometrial cavity

$>$ A gestational sac that is inseperable from adjecent ovarian parenchyma

$>$ A yolk or fetal pole with or without cardiac motion depending upon gestational age.

$>$ Ring of fire sign.

\section{Conclusion}

Although it is a rare occurance the incidence of ovarian pregnancy is on rise. Preoperative diagnosis remains difficult. However USG may assist in early detection although preoperative diagnosis of ovarian ectopic pregnancy remains very challenging the presence of hyperechoic, thick walled mass in the ovary with the absence of 
an identifiable intrauterine pregnancy along with suspicious clinical symptoms and serum $\beta-\mathrm{HCG}$ values should prompt the clinician to consider ovarian ectopic pregnancy as a potential diagnosis.

\section{Bibliography}

1. Hatav GT, Zaynab MD, Leila MD. Ovarian ectopic pregnancy ; a rare Case: Iran J Reprod Med.(2014;12):281-284.

2. Cinthya Sotelo, the journal for Nurse Practitioners 15(2018) 224-227.

3. Cunnigham FG, Lenevo KJ, Bloom SL et al. Ovarian ectopic pregnancy. In: Williams Obstetrics, $25^{\text {th }}$ edn. New York: McGraw-Hill Education, 2018;p384-385. 